\title{
Comparison between prognostic indicators in organ insufficiency with acute pancreatitis
}

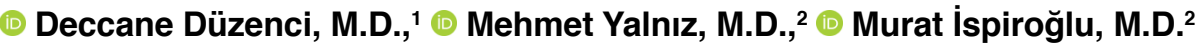

${ }^{1}$ Department of Internal Medicine, Fırat University Facult of Medicine, Elazığ-Turkey

${ }^{2}$ Department of Gastroenterology, Fırat University Facult of Medicine, Elazığ-Turkey

\begin{abstract}
BACKGROUND: Organ failures that develop due to acute pancreatitis (AP), some laboratory values and the anthropometric characteristics of the patients have been shown to play a role in the prognosis AP and have been increasingly used to investigate the prognosis of the disease although classification systems, such as Ranson's criteria, are still used habitually. In this stud, we aimed to investigate the relationship of the organ failures observed during the course of AP, the biochemical parameters and the anthropometric characteristics of the patients and compare using Ranson's and Atlanta Classifica-tion (AC) systems.
\end{abstract}

METHODS: Laboratory values, anthropometric data, including the waist circumference and body mass index, Systemic inflammatory response syndrome (SIRS) and organ failures developed during the course of the disease, were investigated prospectively in I53 AP patients and the Ranson and Modified Atlanta Classifications (MAC) were made.

RESULTS: A relationship was observed between the organ failures that were established in the course of the disease (lung, liver, kidney, heart and MOF (multiple organ failure)) and higher Ranson's and MAC scores $(p<0.05)$. Among the patients included in this study, 13 (8.4\%) had multiple organ failure and 17 (II.I\%) had SIRS. Exitus occurred in 10 patients (6.5\%). A statistically significant relationship was found with organ failure, multiple organ failure and SIRS; and ensuing exitus $(p<0.05)$. While no relationship was observed between the waist circumference, body mass index, Ranson's score, there was a significant relationship between the MAC and the waist circumference $(p<0.01)$. Among the laboratory values, high urea and ALT values showed a relationship with the Ranson and MAC $(p<0.00 \mathrm{I})$, while between the CRP values tested at the 0 time point and the $48^{\text {th }}$ hour, only the CRP value at the $48^{\text {th }}$ hour had a relationship with Ranson's score $(p<0.05)$. Organ failure, MOF, and SIRS showed a correlation with both the severity scores and the mortality rate. In addition, a significant corre-lation was observed between the cholesterol, triglycerides and the CRP level at the time of hospitalisa-tion and mortality. On the contrary, no significant relationship was observed with the other laboratory results, including calcium, lipase and hematocrit.

CONCLUSION: In conclusion, to determine the severity and prognosis of acute pancreatitis, and ex-pect the organ failures that may occur in severe pancreatitis, the body mass index, waist circumference and laboratory values, including cholesterol, triglycerides, ALT, and CRP may supply important prog-nostic data besides the conventional disease severity scoring methods.

Keywords: Acute pancreatitis; organ failure; severity scoring.

\section{INTRODUCTION}

Acute pancreatitis (AP) is a clinical condition where the inactive digestive enzymes within the pancreas become active due to various reasons and digest the pancreas and the surrounding tissues, while its local and systemic effects as well as the resulting inflammation may affect the whole organism. ${ }^{[1]}$
It may not only involve the pancreas and have a mild course but may also lead to complications, such as SIRS and multiple organ failure and prove fatal. ${ }^{[2]}$

Currently, different scoring and classification systems are being used to investigate the severity and prognosis of acute

Cite this article as: Düzenci D, Yalnız M, İspiroğlu M. Comparison between prognostic indicators in organ insufficiency with acute pancreatitis. Ulus Travma Acil Cerrahi Derg 2021;27:410-420.

Address for correspondence: Murat İspiroğlu, M.D.

Fırat Üniversitesi Tıp Fakültesi, Gastroenteroloji Bilim Dalı, Elazığ, Turkey

Tel: +90 344 - 3003746 E-mail: muratispiroglu@yahoo.com

Ulus Travma Acil Cerrahi Derg 2021;27(4):410-420 DOI: 10.14744/tjtes.2020.18552 Submitted: 27.II.2018 Accepted: 09.05.2020

Copyright 202I Turkish Association of Trauma and Emergency Surgery 
pancreatitis (Ranson Criteria, SOFA, LODS, ATLANTA, Imrie Scoring System, APACHE II, Marshall OF scoring). ${ }^{[3-5]}$ Since acute pancreatitis may lead to a wide range of clinical findings, it is rather challenging to use these findings in the evaluation of the disease severity. The Ranson criteria, the most commonly used scoring system is based on the patients' age at the time of admittance and biochemical values, including the WBC count, glucose, LDH, AST and the hematocrit, BUN, $\mathrm{Ca}, \mathrm{PaO} 2$, base deficit and fluid deficit results at the 48th hour. Although either Ranson criteria or its modified form Imrie (Glasgow) may be useful in the early phases of acute pancreatitis, their predictive value diminishes after 48 hours. [5] They also have disadvantage of reproducibility during the course of the disease.

The APACHE (Acute Physiologic and Chronic Health Evaluation) II scoring system is likewise a commonly used system. It may be employed either in the clinical process at the time of hospitalisation or during the hospital stay to evaluate the improvement or worsening in the disease. However, the accuracy of this score has become disputable since higher points are obtained in the older patients due to the age score and the APACHE II scoring system does not include the BMI value although studies in recent years have proven that obesity affects the morbidity and mortality in acute pancreatitis. Thus, the APACHE -0 and APACHE -III scores have been developed. ${ }^{[6]}$

The most comprehensive scoring system in use today is considered to be the Atlanta Scoring System developed in the symposium held in Atlanta in 1992. This system aims to define the standards to describe acute pancreatitis and its complications and thus compare the severity of the disease with the treatment outcomes. The Atlanta criteria in which acute pancreatitis were divided into two sub-groups according to organ failure have later been revised (in 2013) as the Modified Atlanta Classification (MAC) and acute pancreatitis were divided into three sub-groups.

In addition to these scoring systems, certain biochemical parameters like polymorphonuclear leukocyte (PMN) elastase and serum reactive protein (CRP) have been shown as equivalently important and valuable predictors of prognosis in acute pancreatitis. ${ }^{[7]}$ Furthermore, renal failure, respiratory failure, multiple organ failure, fluid deficiency, pancreatic necrosis, longer intensive care requirement and shock, which may be observed in a group of patients, are also indicators of a poor prognosis. ${ }^{[8]}$ Studies in recent years have shown that the evaluation of organ failure and pancreatic necrosis within the first 24 hours after hospitalisation in acute pancreatitis may be used as early prognostic factors to predict the prognosis. The persistent $>48$ hours), multiple organ failure developing at a later stage has also been demonstrated to be associated with a poor prognosis. ${ }^{[9]}$

In the present study, we have compared the frequently used classical prognostic predictors with the Early ( $<24$ hours) and
Late ( $>48$ hours) organ failure data, which have become increasingly and more commonly used in recent years to predict the prognosis in acute pancreatitis patients.

\section{MATERIALS AND METHODS}

This study was approved by Firat University Clinical Research Ethics Committee. A total of 153 consecutive patients between the ages of 19 and 89 , who were diagnosed with acute pancreatitis at the Firat University Hospital, Department of Gastroenterology between 2012 and 2014, were enrolled in this prospective study after their informed consent was obtained.

The diagnosis of acute pancreatitis was based on the clinical examination, laboratory tests and the imaging methods. Acute pancreatitis was diagnosed when two out of the three parameters, including an amylase value $>300 \mathrm{u} / \mathrm{l}$, abdominal pain, and imaging (abdominal USG and/or abdominal CT) findings consistent with acute pancreatitis were positive.

A full physical examination was administered, and the age, sex, demographic characteristics, and comorbidities of all patients were recorded. During the patients' hospital stay, the biochemical parameters, the number of days when oral stop was maintained, and length of the hospital stay were recorded. In the blood samples obtained between 06:00 and 08:00 AM after an 8 to 12-hour fasting period, the complete blood count (CBC), fasting blood glucose (FBG), AST, ALT, INR, total bilirubin, urea, creatinine, calcium, amylase, lipase, cholesterol, triglycerides, $\mathrm{HbAlc}$, insulin and C-peptide values were tested on the same day. To investigate the severity and follow up the course of the inflammation that occured in acute pancreatitis, the CRP levels were tested at the time of hospitalisation and at the $48^{\text {th }}$ hour.

To investigate the insulin resistance, the HOMA score was calculated using the Homeostasis Model Assessment for Insulin Resistance (HOMA-IR) [(fasting insulin $(\mu \mathrm{u} / \mathrm{ml}) \times$ fasting glucose $(\mathrm{mmol} / \mathrm{L})) / 22,5]$ formula. ${ }^{[10]}$

An abdominal USG imaging was performed to investigate the etiology of the disease, and those who could not be diagnosed with the clinical and laboratory findings and/or who were considered to have the severe disease had also undergone abdominal CT scans. The imaging results were recorded. During their hospital stay, patients were closely followed up for the development of local complications (e.g., pancreatic abscess, pancreatic cyst and necrotising pancreatitis), deterioration of the existing organ impairments and/or development of new organ failure and new systemic complications (such as SIRS) due to AP were observed and recorded through the intermittent tests for the $\mathrm{CBC}$, biochemical values and arterial blood gases. Patients lost during the treatment and the cause of death was also recorded. 


\section{Organ Failures and SIRS}

Patients who had organ (lung, kidney, liver and heart) failure were recorded. Based on the time point of hospitalisation, the organ failures that occurred within $\mathbf{4 8}$ hours were defined as Early, while the organ failures that occurred after the initial 48 hours were defined as Late organ failures. Multiorgan failure (MOF) was defined as the failure of at least two organs at the same time point. Diagnosis of liver failure was based on an INR (International Normalized Ratio) value over I.2 or prothrombin time longer than four seconds and a total bilirubin value over $6 \mathrm{mg} / \mathrm{dl}$, while the diagnosis of lung failure was based on an $\mathrm{O} 2$ saturation below $90 \%$ in arterial blood in room air, renal failure was based on basal creatinine levels twice higher and/or - in patients with normal creatinine values - a creatinine level over $1.5 \mathrm{mg} / \mathrm{dl}$, and heart failure was based on

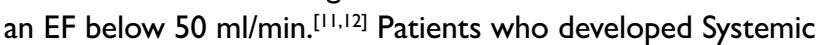
Inflammatory Response Syndrome (SIRS) were also recorded.

\section{Scoring Systems}

The total Ranson scores and the Atlanta scores according to the MAC were calculated for all the patients. The patients enrolled in this study were divided into groups: The Ranson scores at hour 0 (zero) and the 48th hour were calculated and added. The patient group with total Ranson scores $<3$ was named as Ranson 0, while the group with total Ranson scores $\geq 3$ was named as Ranson I. According to the MAC, patients were classified into three groups as follows: 0: mild pancreatitis, I: moderate pancreatitis, 2: severe pancreatitis. [13-15] According to the Modified Marshall score, the patients' respiratory system, kidney function, and circulation was evaluated and scores $>2$ in any organ were defined as organ failure. ${ }^{[16]}$

\section{Statistical Analyses}

Data obtained from this study were uploaded to the Statistical Package for the Social Sciences (SPSS 17.0, Chicago, 2009, IL, USA) software. The numeric data from this study were analysed using one-way ANOVA, while the non-numeric values were analysed through the Chi-square test. The results were expressed as mean \pm standard deviation. The relationship between certain parameters was tested using the correlation test. The obtained results were assessed within the $95 \%$ confidence interval based on a significance level of $p<0.05$.

\section{RESULTS}

Among 153 acute pancreatitis patients with a mean age of 59 $( \pm 19.7)$ (59 males [38.6\%], 94 females [6I.4\%]), the leading

Table Ia. Comparison of the biochemical and anthropometric values with Ranson Scores

\begin{tabular}{|c|c|c|c|}
\hline & \multicolumn{3}{|c|}{ Ranson Scores } \\
\hline & $0(0-I-2)$ & $I(\geq 3)$ & $\mathbf{p}$ \\
\hline Age & $52.9 \pm 19.6$ & $7 I \pm 13.4$ & 0.000 \\
\hline Body mass index & 28.2 .53 & $27.9 \pm 5.9$ & 0.728 \\
\hline Waist circumference & $93.4 \pm 13.5$ & $93.3 \pm 5.9$ & 0.987 \\
\hline Glucose (mg/dl) & $129.3 \pm 56.3$ & $156.6 \pm 61.2$ & 0.009 \\
\hline Urea day 0 (mg/dl) & $33.1 \pm 16.6$ & $47.2 \pm 26.7$ & 0.001 \\
\hline Urea day I (mg/dl) & $30.5 \pm 16.3$ & $47.3 \pm 31.6$ & 0.001 \\
\hline Urea day 2 (mg/dl) & $26.9 \pm 15.7$ & $39.1 \pm 27.9$ & 0.006 \\
\hline AST (u/l) & $178.7 \pm 209.3$ & $429.3 \pm 381$ & 0.000 \\
\hline ALT (u/l) & $182.5 \pm 226$ & $356.7 \pm 286$ & 0.000 \\
\hline Calcium (mg/dl) & $9.1 \pm 0.64$ & $8.8 \pm 0.6$ & 0.07 \\
\hline Amylase (u/l) & $1653.2 \pm 1095$ & $1762.7 \pm \mid 309.2$ & 0.612 \\
\hline Lipase (u/l) & $74 I \pm 1062.9$ & $749 \pm 884.7$ & 0.982 \\
\hline $\mathrm{HbAlc}$ & $5.9 \pm 2.7$ & $7.6 \pm 2.5$ & 0.143 \\
\hline Cholesterol (mg/dl) & $170.5 \pm 54.9$ & $190.6 \pm 69.5$ & 0.086 \\
\hline Triglycerides (mg/dl) & $|48.6 \pm 22|$ & $|4| \pm 82.4$ & 0.770 \\
\hline Crp day $0(\mathrm{mg} / \mathrm{l})$ & $34.5 \pm 65.3$ & $51 \pm 66.7$ & 0.158 \\
\hline Crp $\geq$ day $2(\mathrm{mg} / \mathrm{l})$ & $38 \pm 59.5$ & $69.2 \pm 69.7$ & 0.011 \\
\hline Homa Score & $1.95 \pm 3.24$ & $2.23 \pm 2.3$ & 0.569 \\
\hline Median hospital stay (days) & $8 \pm 4.6$ & $9 \pm 6.1$ & 0.310 \\
\hline Oral stop (days) & $3.3 \pm 1.8$ & $5.8 \pm 16.9$ & 0.281 \\
\hline
\end{tabular}

ALT: Alanine aminotransferase; AST: Aspartate aminotransferase. 
cause was biliary stones in $73.9 \%$, followed by idiopathic causes in $21.6 \%$ and other causes with $4.6 \%$.

According to Ranson's classification, acute pancreatitis was mild in 101 patients (66\%: Female 60,4\%, Male 39.6\%), while it was severe in 52 patients (34\%: Female 63.5\%, Male 36.5\%). Concerning the MAC, $61.7 \%$ of the females, $62.7 \%$ of the males were in Group 0., $26.6 \%$ of the Females, $27.1 \%$ of the Males were in Group I and II.7\% of the Females, $10.2 \%$ of the males were in Group 2. Sex was not a significant factor in determining the severity or prognosis of acute pancreatitis. ( $p>0.05$ for all).

The age, BMI, waist circumference and biochemical parameters, including urea, glucose, AST, ALT, amylase, lipase, calcium, CRP, cholesterol and $\mathrm{HbAlc}$, were compared in relation to the Ranson and Modified Atlanta Classification. There was a significant relationship between the urea, glucose, age, the $2^{\text {nd }}$ day CRP, ALT and AST values and the severity and prognosis of AP according to the Ranson score $(p<0.05)$ (Table Ia). On the other hand, the urea, glucose, age, waist circumference, and cholesterol values were associated with severity of AP regarding the MAC criteria $(p<0.05)$ (Table Ib).
Comorbid disease evaluation involved patients with one or more of the conditions, including hypertension, type 2 DM, ischemic heart disease, malignancies or COPD, and patients without comorbid diseases. Among the 149 patients who were included in the Ranson classification, while $24.4 \%$ of (19/78) the patients in Ranson Group 0 had comorbidities, $46.5 \%$ (33/7I) of patients in the Ranson Group I had comorbidities. When the patients with comorbidities in the Ranson classification were compared with those without comorbidities, the $p$-value was significant $(p<0.05)$. Among the 153 patients who were classified according to the MAC criteria, out of the 101 patients who did not have comorbid diseases according to MAC, particularly 73 (72.3\%) were in Group 0 . When those with comorbid diseases in MAC were compared with those without comorbid diseases, the influence of comorbidity on the severity and prognosis of AP was found as $p<0.05$ (Table 2). These results pointed out a significant relationship between the comorbidity and the severity of AP.

The role of the etiology of AP on the prognosis was also investigated in this study. The etiological factors were divided into three groups, including idiopathic causes, choledochal stones, and others, and these were compared with Ranson Group 0 and I as well as MAC Group 0 , I and 2, but no signif-

Table Ib. Comparison of the biochemical and anthropometric values with MAC scores

\begin{tabular}{|c|c|c|c|c|}
\hline & \multicolumn{4}{|c|}{ Modified Atlanta Classification Scores } \\
\hline & 0 (mild) & I (moderate) & 2 (severe) & $\mathbf{p}$ \\
\hline Age & $51.6 \pm 19.4$ & $71.3 \pm 12.9^{* * *}$ & $70.8 \pm 13.2^{* * * *}$ & 0.000 \\
\hline Body mass index & $27.8 \pm 5.2$ & $29 \pm 5.9$ & $27.7 \pm 1.3$ & 0.461 \\
\hline Waist circumference & $90.6 \pm 12.3$ & $99.7 \pm 15^{* *}$ & $93.5 \pm 14$ & 0.002 \\
\hline Glucose (mg/dl) & $127.3 \pm 44.2$ & $164.1 \pm 77.3^{* *}$ & $|40| \pm 67.2$. & 0.004 \\
\hline Urea day 0 (mg/dl) & $32.2 \pm 15.9$ & $46.3 \pm 23.7^{7 *}$ & $48.8 \pm 32.4^{* *}$ & 0.000 \\
\hline Urea day I (mg/dl) & $28.4 \pm 13.8^{+++}$ & $46.2 \pm 29.6^{* * *}$ & $56.1 \pm 33.3^{* * *}$ & 0.000 \\
\hline Urea day 2 (mg/dl) & $26.1 \pm 15.2^{++}$ & $38.7 \pm 29.2^{* *}$ & $40.5 \pm 21.6^{*}$ & 0.001 \\
\hline AST (u/l) & $236.6 \pm 254.2$ & $290.7 \pm 329.9$ & $351.5 \pm 451.8$ & 0.286 \\
\hline ALT (u/l) & $230.3 \pm 246$ & $253.2 \pm 283$ & $278.1 \pm 293$ & 0.746 \\
\hline Calcıum (mg/dl) & $9.1 \pm 0.6$ & $8.8 \pm 0.6$ & $9 \pm 0.6^{* *}$ & 0.002 \\
\hline Amylase (u/l) & $1627.2 \pm 1094.5$ & $1646.7 \pm 1065.1$ & $2132 \pm 1676.7$ & 0.252 \\
\hline Lıpase (u/l) & $624.7 \pm 944.1$ & $903 \pm 682.7$ & $603.8 \pm 970.1$ & 0.541 \\
\hline Cholesterol (mg/dl) & $167.1 \pm 39.4$ & $200.3 \pm 93.1^{*}$ & $178.2 \pm 39.1$ & 0.017 \\
\hline Triglycerides (mg/dl) & $137.7 \pm 156$ & $175.7 \pm 260$ & $116.7 \pm 70.6$ & 0.470 \\
\hline Crp day $0(\mathrm{mg} / \mathrm{l})$ & $37.7 \pm 60.8$ & $35.5 \pm 73.3$ & $65.1 \pm 74.5$ & 0.273 \\
\hline Crp day $2(\mathrm{mg} / \mathrm{l})$ & $50.4 \pm 67.1$ & $46.8 \pm 65.5$ & $45.5 \pm 50.5$ & 0.941 \\
\hline Homa score & $1.6 \pm 1.9$ & $2.6 \pm 3.6$ & $3.2 \pm 5.4$ & 0.075 \\
\hline Median hospital stay (days) & $7.9 \pm 4.7$ & $9.7 \pm 6.1$ & $7.9 \pm 4.6$ & 0.173 \\
\hline Oral stop (days) & $4.4 \pm 12.6$ & $3.6 \pm 1.8$ & $3.6 \pm 1.2$ & 0.886 \\
\hline
\end{tabular}


Table 2. Comparison of the comorbidity with Ranson and MAC

\begin{tabular}{|c|c|c|c|c|c|c|c|c|c|c|c|c|c|}
\hline \multirow{2}{*}{$\frac{\text { Ranson }}{\text { Comorbidity }}$} & \multicolumn{2}{|c|}{ Group 0} & \multicolumn{2}{|c|}{ Group I } & \multirow[t]{2}{*}{$\mathbf{p}$} & \multirow{2}{*}{$\frac{\text { MAC }}{\text { Comorbidity }}$} & \multicolumn{2}{|c|}{0 (mild) } & \multicolumn{2}{|c|}{ I (moderate) } & \multicolumn{2}{|c|}{2 (severe) } & \multirow[t]{2}{*}{$\mathbf{p}$} \\
\hline & n (149) & $(\%)$ & n (149) & (\%) & & & n (153) & (\%) & n (153) & (\%) & n (I53) & $(\%)$ & \\
\hline No $(n=97)$ & 59 & 75.69 & 38 & 53.5 & 0.006 & No $(n=|0|)$ & 73 & 72.3 & 21 & 20.8 & 7 & 6.9 & 0.001 \\
\hline Yes $(n=52)$ & 19 & 24.4 & 33 & 46.5 & & Yes $(n=52)$ & 22 & 42.3 & 20 & 38.5 & 10 & 19.2 & \\
\hline
\end{tabular}

$\mathrm{P}<0.05$ : Statistical significance level. MAC: Modified Atlanta Classification.

icant difference was found. In all the patients included in this study, any history of cholecystectomy was investigated parallel to imaging and 16 out of the 153 patients were observed to have an acute pancreatitis attack despite a past cholecystectomy. Although the most common cause of acute pancreatitis in our country is bile stones, it was also observed that cholecystectomy did not prevent AP in a group of patients. However, the acute pancreatitis attack in the patients with a history of cholecystectomy (87.5\%) had a milder course. The difference in the severity of AP between the patients with a history of cholecystectomy and those without past cholecystectomy, however, was statistically insignificant.

The effects of the local complications (fluid collection, cyst, necrosis, infected necrosis) detected using the imaging methods upon the prognosis of AP was also examined. Seventy-five patients (49\%) who were suspected of having local complications based on the physical examination, laboratory results and USG imaging had undergone computed tomography at the 48th hour or later and the local complications in the pancreas detected through the scans were recorded. Concerning local complications, 58 patients $(37.9 \%)$ had fluid collection around the pancreas, six patients $(3.9 \%)$ had pancreatic cysts, four patients $(2.6 \%)$ had non-complicated necrosis, and seven patients (4.5\%) had infected necrosis; while no local complications developed in 78 patients $(50.9 \%)$. These complications were compared with Ranson Groups 0, I and the MAC Groups 0, I, 2 and the local complications occurring during the course of the disease did not influence the prognosis in AP $(p>0.05)$.

According to Ranson, in mild cases of acute pancreatitis, the mean CRP values were $34.5 \mathrm{mg} / \mathrm{dl}( \pm)$ at day 0 and $70 \mathrm{mg} / \mathrm{dl}$ $( \pm)$ at day 2. Between mild AP and severe AP, a significant relationship $(P<0.05)$ was observed concerning the mean length of hospital stay in days and the CRP values; the difference was 2-fold. According to Ranson's classification, the mean number of oral stop days was three $( \pm I .8)$ in the patients with mild attacks of acute pancreatitis, while this number was six $( \pm 16.9)$ in severe pancreatitis $(p=0.28 \mathrm{I})$.

SIRS developed in 17 (II.I\%) patients. Among these cases of SIRS, 10 were diagnosed at the time of admittance (Early SIRS), while seven occurred within 48 hours (Late SIRS). In four patients with Early SIRS, the condition was sustained after the $48^{\text {th }}$ hour (persistent SIRS). SIRS was present only in three out of 10 (30\%). AP patients with mortality, while seven were free of SIRS. Among the patients who died, one patient was diagnosed with Early SIRS at the time of admittance. Late SIRS developed in two, which continued as persistent SIRS in the following days.

Out of the 153 patients included in this study with the diagnosis of acute pancreatitis, $7 \mathrm{I}(46.4 \%)$ had single or multiple organ failures, while 82 (53.5\%) developed no organ failure during their hospital stay. The leading organ failure was early lung failure observed in 35 patients (22.9\%), followed by early kidney failure in $14.4 \%$ and late liver failure in $5.2 \%$. Multiple organ failure was observed in only 13 (8 female, 5 male) patients (8.5\%). Outstandingly, exitus occurred in six of these 13 patients (46.5\%). To evaluate the relationship between the organ failure that has developed during the treatment of the patients with AP enrolled in our study and the severity and prognosis of the disease, organ failures were compared with Ranson and MAC. Also, the organ failures were divided into two groups within themselves as Early organ failure $\leq 48$ hours and $>48$ hours and were compared with Ranson and MAC values. Except the liver failure a significant relationship was observed between the kidney failure, lung failure, heart failure and Ranson and MAC ( $p<0.05)$ (Table 3).

In our study, the influence of the patients with or without organ failure according to the Modified Marshall scoring system, those with or without multiple organ failure, and those in which SIRS developed within $<48$ hours or $>48$ hours, on the severity and prognosis of the disease was investigated in comparison to the Ranson and MAC scores. According to the Modified Marshall system, among the 124 patients without organ failure 91 (73.4\%) were in Ranson Group 0 and 33 (26.6\%) in Ranson Group I. Among the patients with organ failure according to the Modified Marshall system 10 (34.5\%) were in Ranson Group 0, 19 (65.5\%) were in Ranson Group I. The Modified Marshall score was observed to have a relationship with the severity and prognosis of the disease $(p<0.05)$. Similarly, when the Modified Marshall organ failure scoring system was compared with the MAC, the same statistically significant $p$-value was found. Like the Marshall organ failure score, the multiple organ failure was also compared to the Ranson and MAC Groups and the $p$-value indicated a relationship with these parameters $(p<0.05)$. Patients in 
Table 3. Comparison of Ranson and Modified Atlanta Classification according to the organ failure

\begin{tabular}{|c|c|c|c|c|c|c|c|c|}
\hline \multirow[t]{2}{*}{ Ranson } & \multicolumn{3}{|c|}{$0(n=101 / 153)$} & \multicolumn{4}{|c|}{ I $(n=52 / 153)$} & \multirow[t]{2}{*}{$\mathbf{p}$} \\
\hline & $\mathbf{n}$ & & $\%$ & & $\mathbf{n}$ & & & \\
\hline \multicolumn{9}{|l|}{ Early liver failure } \\
\hline 0 (No) & 97 & & 65.9 & & 50 & & & 0.553 \\
\hline I (Yes) & 4 & & 66.6 & & 2 & & & \\
\hline \multicolumn{9}{|l|}{ Late liver failure } \\
\hline 0 (No) & 96 & & 66.2 & & 49 & & & 0.020 \\
\hline I (Yes) & 5 & & 62.5 & & 3 & & & \\
\hline \multicolumn{9}{|l|}{ Early kidney failure } \\
\hline 0 (No) & 92 & & 70.2 & & 39 & & & 0.007 \\
\hline I (Yes) & 9 & & 40.9 & & 13 & & & \\
\hline \multicolumn{9}{|l|}{ Late kidney failure } \\
\hline 0 (No) & 95 & & 67.9 & & 45 & & & 0.130 \\
\hline I (Yes) & 6 & & 45.5 & & 7 & & & \\
\hline \multicolumn{9}{|l|}{ Early lung failure } \\
\hline 0 (No) & 87 & & 73.7 & & 31 & & & 0.000 \\
\hline I (Yes) & 14 & & 40.0 & & 21 & & & \\
\hline \multicolumn{9}{|l|}{ Late lung failure } \\
\hline 0 (No) & 100 & & 68.5 & & 46 & & & 0.001 \\
\hline I (Yes) & 0 & & 0 & & 6 & & & \\
\hline \multicolumn{9}{|l|}{ Heart failure } \\
\hline 0 (No) & 90 & & 71.4 & & 36 & & & 0.002 \\
\hline I (Yes) & 11 & & 40.7 & & 16 & & & \\
\hline \multirow[t]{2}{*}{$\begin{array}{l}\text { Modified Atlanta } \\
\text { Classification }\end{array}$} & \multicolumn{2}{|c|}{$\begin{array}{c}0 \text { (mild disease) } \\
n=95 / 153\end{array}$} & & \multicolumn{2}{|c|}{$\begin{array}{c}\text { I (moderate disease) } \\
n=4 \mid / / 53\end{array}$} & \multicolumn{2}{|c|}{$\begin{array}{c}2 \text { (severe disease) } \\
n=17 / / 53\end{array}$} & $\mathbf{p}$ \\
\hline & $\mathbf{n}$ & $\%$ & & $\mathbf{n}$ & $\%$ & $\mathbf{n}$ & $\%$ & \\
\hline \multicolumn{9}{|l|}{ Early liver failure } \\
\hline No & 91 & 61.9 & & 40 & 27.2 & 16 & 10.8 & 0.446 \\
\hline Yes & 4 & 66.6 & & 1 & 16.7 & 1 & 16.7 & \\
\hline \multicolumn{9}{|l|}{ Late liver failure } \\
\hline No & 93 & 64.5 & & 38 & $26.3^{+++}$ & 13 & $9.0^{* * *}$ & 0.000 \\
\hline Yes & 2 & 25 & & 2 & 25 & 4 & 50 & \\
\hline \multicolumn{9}{|l|}{ Early kidney failure } \\
\hline No & 94 & 71.8 & & 24 & $18.3^{* * * *}$ & 13 & $9.9^{*}$ & 0.000 \\
\hline Yes & 1 & 4.5 & & 17 & 77.3 & 4 & 18.2 & \\
\hline \multicolumn{9}{|l|}{ Late kidney failure } \\
\hline No & 94 & 87.2 & & 37 & 26.4 & 9 & $6.4^{* * * /++++}$ & 0.000 \\
\hline Yes & 0 & 0 & & 3 & 27.3 & 8 & 72.7 & \\
\hline \multicolumn{9}{|l|}{ Early lung failure } \\
\hline No & 95 & 80.5 & & 15 & $12.7^{* * *}$ & 8 & $6.8^{* * *}$ & 0.000 \\
\hline Yes & 0 & 0 & & 26 & 74.3 & 9 & 25.7 & \\
\hline \multicolumn{9}{|l|}{ Late lung failure } \\
\hline No & 94 & 64.4 & & 39 & 26.7 & 13 & $8.9^{* * * /++++}$ & 0.000 \\
\hline Yes & 0 & 0 & & 1 & 20.0 & 4 & 80 & \\
\hline \multicolumn{9}{|l|}{ Heart failure } \\
\hline No & 88 & 69.8 & & 25 & $19.8^{* * *}$ & 13 & 10.3 & 0.000 \\
\hline Yes & 7 & 25.9 & & 16 & 59.3 & 4 & 14.8 & \\
\hline
\end{tabular}

$\mathrm{P}<0.05$ : statistical significance level is. Compared to $0(\mathrm{p}<0.05: * / \mathrm{p}<0.01: * * / p<0.001: * * *)$. Compared to I $(\mathrm{p}<0.05:+/ \mathrm{p}<0.01:++/ \mathrm{p}<0.001:+++)$. 
which SIRS developed within $<48$ hours or $>48$ hours were also compared with Ranson and MAC in terms of statistical significance. The SIRS value for $<48$ hours was significant in relation to the MAC $(p=0.045)$, while the $p$-value for other parameters was $p>0.05$ (Table 4).

Table 5 summarizes the relationship between the laboratory results, anthropometric data, organ failures, Ranson classification, Atlanta classification and SIRS in the patients with AP. Spearman's correlation test revealed a statistically significant positive correlation between the Ranson scores, MAC and Marshall classification in terms of the organ failures and the urea values recorded at the time of admission, while no correlation was found with the anthropometric values. Also, when mortality was compared with the organ failure, SIRS, and laboratory results, a significant positive correlation was found with all the organ failures, SIRS, high urea values and mortality $(p<0.01)$. Among the laboratory values, the ALT, AST, CRP Day 0 and CRP Day 2 showed a positive correlation with the Ranson scores. A positive correlation was also observed with the high CRP values and liver failure (Table 5).

Out of all the parameters evaluated, only the patients' glucose, age, cholesterol, triglycerides and high CRP values at the time of hospitalisation had a relationship with mortality $(p<0.05)$, while the BMI, waist circumference, length of hospital stay in days, etiology, comorbid diseases, and biochemical parameters, such as calcium, lipase and Htc, were not asso-

Table 4. Comparison of the Marshall, multiple organ failure and SIRS parameters with the Ranson and MAC

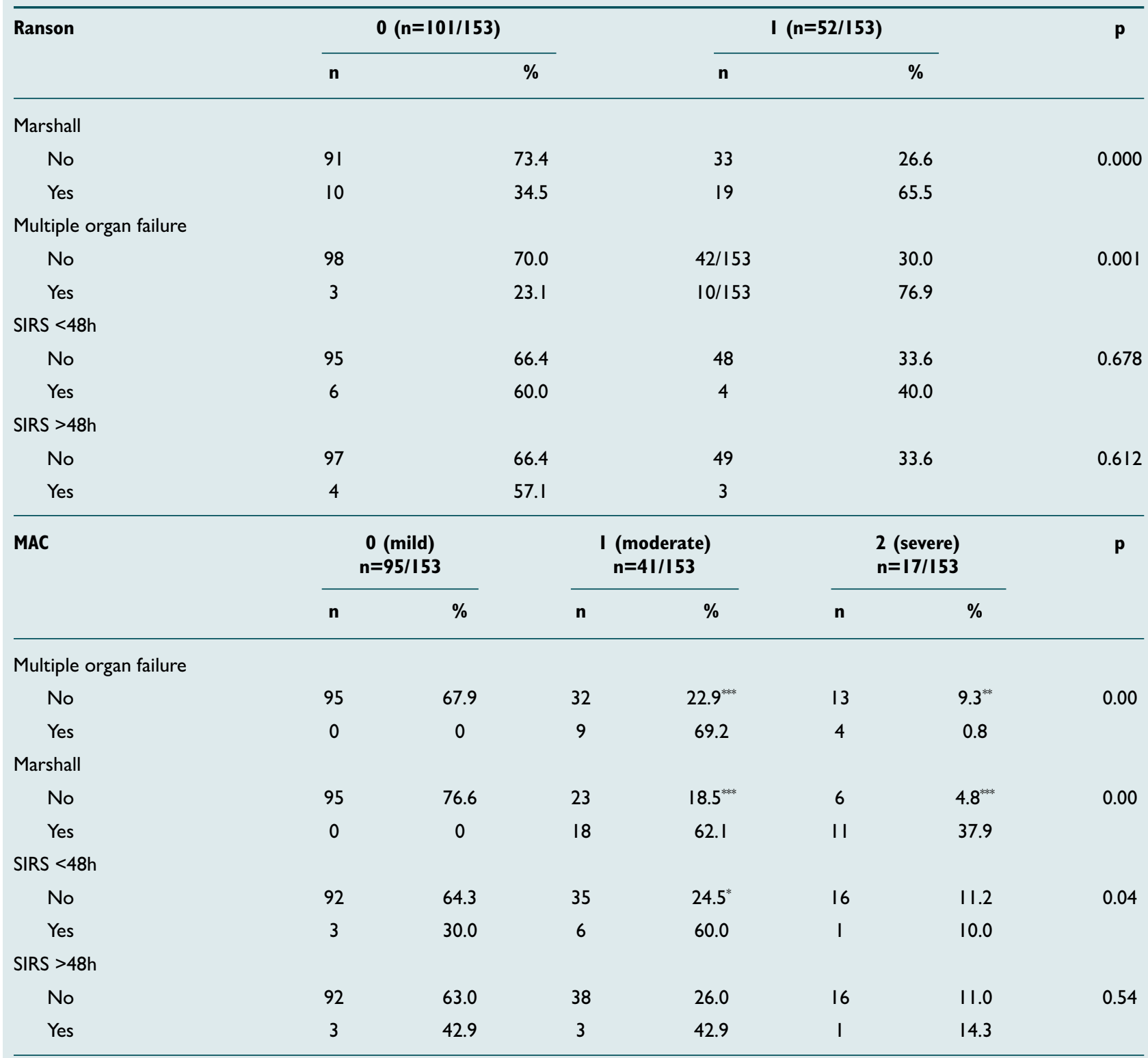

P $<0.05$ : statistical significance level. Compared to 0 ( $p<0.05: * / p<0.01: * * / p<0.001: * * *)$. Compared to I $(p<0.05:+/ p<0.01:++/ p<0.001:+++)$. SIRS: Systemic Inflammatory Response Syndrome; MAC: Modified Atlanta Classification; 
Table 5. Comparison of the laboratory parameters, anthropometric values and organ failure in patients with acute pancreatitis

\begin{tabular}{|c|c|c|c|c|c|c|c|c|c|c|}
\hline \multirow[t]{2}{*}{ Organ failure } & E. Liver & L. Liver & E. Kidney & L. Kidney & E. Lung & L. Lung & Multiple organs & SIRS & Urea & Ranson \\
\hline & $\mathbf{r}$ & $\mathbf{r}$ & $\mathbf{r}$ & $\mathbf{r}$ & $\mathbf{r}$ & $\mathbf{r}$ & $\mathbf{r}$ & $\mathbf{r}$ & $\mathbf{r}$ & $\mathbf{r}$ \\
\hline Ranson & 0.007 & $0.189^{*}$ & $0.217^{* *}$ & 0.123 & $0.299^{* *}$ & $0.259^{* *}$ & 0.276 & 0.034 & $0.321^{* *}$ & - \\
\hline MAC & 0.123 & $0.478^{* *}$ & $0.444^{* *}$ & $0.443^{* *}$ & $0.666^{* *}$ & $0.333^{* *}$ & 0.384 & 0.150 & $0.347^{* *}$ & $0.299^{* *}$ \\
\hline Marshall & $0.170^{*}$ & $0.399^{* *}$ & $0.420^{* *}$ & $0.456^{* *}$ & $0.491^{* *}$ & $0.293^{* *}$ & $0.570^{* * *}$ & $0.277^{* *}$ & $0.365^{* *}$ & $0.322^{* *}$ \\
\hline BMI & -0.015 & -0.062 & 0.021 & 0.023 & 0.130 & 0.023 & 0.075 & 0.052 & -0.120 & -0.020 \\
\hline Waist circumference & -0.070 & 0.053 & 0.141 & 0.040 & $0.213^{* *}$ & 0.022 & 0.101 & 0.045 & -0.099 & -0.005 \\
\hline ALT & 0.018 & 0.029 & -0.005 & 0.040 & 0.029 & 0.023 & 0.016 & -0.017 & 0.019 & $0.388^{* *}$ \\
\hline AST & 0.052 & 0.047 & -0.016 & 0.089 & 0.074 & -0.003 & 0.016 & -0.012 & 0.111 & $0.422^{* *}$ \\
\hline CRP day 0 & $0.198^{*}$ & $0.219^{*}$ & 0.005 & 0.151 & -0.080 & 0.175 & 0.041 & 0.025 & 0.125 & $0.216^{* *}$ \\
\hline CRP day 2 & $0.198^{*}$ & 0.167 & 0.007 & 0.079 & 0.012 & $0.189^{*}$ & 0.003 & -0.002 & 0.100 & 0.267 \\
\hline Ex & $0.185^{*}$ & $0.350^{* *}$ & $0.193^{* *}$ & $0.468^{* * *}$ & $0.297^{* *}$ & $0.266^{* *}$ & $0.488^{* * *}$ & $0.144^{*}$ & $0.266^{* *}$ & $0.257^{* *}$ \\
\hline
\end{tabular}

"P<0.05 statistically significant correlation; " $P<0.01$ statistically significant correlation. SIRS: Systemic Inflammatory Response Syndrome; MAC: Modified Atlanta Classification; BMI: Body mass index; ALT: Alanine aminotransferase; AST: Aspartate aminotransferase; CRP: C-reactive protein.

ciated with mortality $(p>0.05)$. The mean age of the 10 mortalities was 73, their mean duration of hospital stay was 8.4 days ( $I$ to 34 days), and the mean BMI was $28.4 \mathrm{~kg} / \mathrm{m}^{2}$. Also, the mean CRP value of the mortalities at the time of hospitalisation was $65 \mathrm{mg} / \mathrm{dl}$ and the mean CRP at 48 hours was 81 $\mathrm{mg} / \mathrm{dl}$. The MAC score was calculated as two in five patients $(50 \%)$ and one in five patients (50\%). Except for one patient, the organ failure was observed in all the patients according to the Modified Marshall score. Among the mortalities, eight (80\%) were lost due to lung and kidney failure at the Early and Late stages, while two (20\%) were lost due to infection. The length of hospitalisation of these patients varied between one and 34 days.

\section{DISCUSSION}

Bile stones and alcoholism account for approximately $80 \%$ of the AP cases, while the cause remains unknown in approximately $10 \%$ of the cases, which are defined as idiopathic. In our study, $73.8 \%$ of the patients had acute pancreatitis due to stones, $21.5 \%$ had the idiopathic disease, and other causes (high triglycerides, ampulla Vater diverticulitis, sclerosing cholangitis, fasciola hepatica, autoimmune pancreatitis, chronic pancreatitis) were responsible in the remaining $4.5 \%$. In the case of bile stones, cholecystectomy is a commonly used treatment method for the prophylaxis of AP around the world. ${ }^{[17,18]}$ Although we have also observed similar findings in our study, given that $16(10.4 \%)$ out of the 153 patients included in the study developed AP despite a past cholecystectomy shows that cholecystectomy alone does not prevent AP. However, the AP in the patients with a history of cholecystectomy found to had a milder course.

The disease may only affect the pancreas and progress slightly, as well as lead to complications that may lead to multiple organ failure. ${ }^{[2]}$ Approximately 15 to 25 percent of all patients with acute pancreatitis (AP) develop severe AP. Between 1988 and 2003, mortality from acute pancreatitis decreased from 12 percent to 2 percent, according to a large epidemiologic study. ${ }^{[19]}$ The ability to predict its severity can help identify patients at increased risk for morbidity and mortality, thereby assisting in appropriate early triage to intensive care units and selection of patients for specific interventions. While scoring systems, including the Ranson and Atlanta criteria, are used to determine the severity and prognosis of acute pancreatitis; renal failure, respiratory failure, multiple organ failure, fluid deficiency, pancreatic necrosis, longer intensive care requirement, and shock, which may be observed in a group of patients, are additional indicators of a poor prognosis. ${ }^{[9]}$

The Ranson and MAC criteria are used to determine the severity and prognosis in AP, and a recent study has demonstrated that the comorbid diseases (such as hypertension, ischemic heart disease or type $2 \mathrm{DM}$ ) accompanying AP (may also negatively influence the severity and prognosis of the disease. ${ }^{[20]}$ Similarly, we observed that the AP attack in the patients with comorbidities had a severe disease of $63.4 \%$, according to Ranson, while $36.5 \%$ had a mild course. Among the patients with comorbid diseases according to MAC, $57.7 \%$ had a moderate or severe AP attack. This observation where the statistical difference was significant showed us that AP had a more severe course in the patients with comorbidities and underlined the need to follow up these patients more closely.

Among the important results obtained from our study was the significant relationship of the Early and Late organ failure (liver, kidney and heart) with the severity of the disease according to the Ranson and MAC scores. According to both the Ranson's and MAC classifications, the patients with organ failures had a severe attack. Early and persistent organ failure is a reliable indicator of a prolonged hospital stay and 
increased mortality. In one report, organ failure within 72 hours of admission was associated with the presence of extended pancreatic necrosis and a mortality rate of 42 percent. [21] Several subsequent studies found that the evolution and clinical course of organ failure was a more accurate predictor of adverse outcomes. In one study, persistent and deteriorating ( $\geq 48$ hours) organ failure were associated with mortality rates of 21 and 55 percent, respectively. ${ }^{[22]}$

In light of these results, especially during the treatment of patients with severe AP, the risk of lung, liver, kidney and heart failure should be borne in mind.

In a similar literature study conducted on 127 patients, a significant relationship was observed between the severity of the disease and organ failure in the patients with AP. The resulting organ failures were associated with a negative effect on the prognosis of the disease and mortality. ${ }^{[23]}$ This study also supports our results and emphasizes the influence of organ failure on disease prognosis and mortality in AP, as well as underlining the importance of the follow-up for organ failure in these patients.

Another focus of our study was the relationship of multiple organ failure, Marshall organ failure, and SIRS development with the Ranson and MAC scores in the patients who had severe AP according to these scoring systems, as well as the relationship with the prognosis of the disease. Among the patients who had organ failure according to the Marshall organ failure classification, $65.5 \%$ had severe AP, while this ratio was $76.9 \%$ among those with multiple organ failure. These results demonstrated the statistically significant relationship between the severity of pancreatitis and organ failures.

Neither Early (<48 hours) nor Late SIRS developed in AP patients pointed to a significant relationship between the Ranson score. On the other hand, a significant relationship was observed with Early SIRS development according to the MAC and the severity of AP, while no significant relationship was found between Late SIRS and the severity of AP. In a similar study, 127 patients who were diagnosed with AP were retrospectively evaluated and the Modified Marshall score was compared with the organ failures and development of SIRS. Although there was a relationship between the severity of AP and the organ failures, no relationship was observed between the SIRS and the severity of AP. ${ }^{[23]}$

In a prospective study conducted between 2008 and 2012, the waist circumference and BMI values of the 384 AP patients were classified and compared according to Ranson and MAC. The results pointed out a significant relationship between the severity of the AP and the anthropometric values. [24] However, in the present study, BMI and waist circumference were not associated with Ranson score, while MAC severity score had a significant relationship between the waist circumference and the severity of AP. The lack of a significant relationship with the Ranson values was explained by the late presentation of certain patients to our hospital and the resulting lower Ranson scores. Considering both our study and the previous study, we believe that central obesity may be defined as a negative prognostic factor in the course of AP.

Regarding the biochemical parameters analysed in patients with AP, a significant relationship was observed between higher Ranson scores and the urea, AST, ALT and $48^{\text {th }}$-hour CRP-values. Although there was a significant relationship between the MAC score and the urea result, no association was observed with the AST, ALT and CRP-values. On the other hand, CRP, AST and ALT values of the AP patients with higher Ranson scores were highly and positively correlated with the Ranson score.

In the light of these results, we are of the opinion that we can predict the prognosis of the disease based on biochemical results, such as higher urea, AST and ALT values. Also, supporting our view, in a study conducted on 60 severe pancreatitis patients and a control group (where the patients' AST, ALT and urea test results were also high as in our patients), a group of patients had undergone hemofiltration and higher parameters were reduced within normal laboratory limits. While the severity and prognosis of AP were poorer in the control group, the prognosis was better in the group that had undergone hemofiltration. ${ }^{[25]}$

In eight patients, exitus occurred due to Early or Late lung and kidney failure, while two patients were lost due to infections. In these patients, the length of the hospital stay varied between I and 34 days and the mean length of the hospital stay was 8.4 days. Also, among the tested CRP, Htc and BMI values in the patients included in the study and resulted in exitus, the CRP-value was related with mortality, whereas no relationship was observed between the Htc and BMI value and mortality. In a similar study that included 72 patients with AP, the relationship between the AP scoring system, higher CRP values and mortality was evaluated, and in line with this study, a relationship between higher CRP values and mortality was observed. ${ }^{[26]}$

The overall mortality rate is $3 \%$ to $10 \%$, but patients with the severe form of the disease are at an increased risk of death, with a mortality rate of $36 \%$ to $50 \% .^{[27-29]}$ Persistent organ failure is widely accepted as a reliable criterion for severe AP. A systematic review of predictors of persistent organ failure (severe acute pancreatitis) and infected pancreatic necrosis found blood urea nitrogen useful for prediction of persistent organ failure after 48 hours of admission and procalcitonin for prediction of infected pancreatic necrosis. ${ }^{[30]}$ On the other hand, early organ dysfunction that was not persistent $(<48$ hours) was associated with a mortality rate of 0 percent. In our study, 10 patients with AP $(6.5 \%)$ resulted in exitus and a significant relationship was observed between the severe of disease and the occurrence of exitus. However, there was 
was no relationship between the length of the hospital stay and exitus.

In conclusion, although scoring systems, such as the Ranson and Atlanta classifications, have been in use for years to investigate the severity and prognosis of acute pancreatitis, according to the results of both our study and similar studies, we can also have an idea about the severity and prognosis of the disease through more simple data, such as the BMI, waist circumference and biochemical parameters in addition to these scoring systems. The development of organ failure is the most significant indicator that the disease is severe and has a poor prognosis. It was concluded that more care should be taken, especially in comorbid cases.

Ethics Committee Approval: This study approved by the Firat University Non-Interventional Research Ethics Committee (Date: 05.09.2013, Decision No: 03-06).

Peer-review: Internally peer-reviewed.

Authorship Contributions: Concept: M.Y.; Design: M.Y., M.I.; Supervision: M.Y.; Materials: D.D.; Data: D.D.; Analysis: M.I., M.Y.; Literature search: M.I.; Writing: D.D., M.I.; Critical revision: M.I.

\section{Conflict of Interest: None declared.}

Financial Disclosure: The authors declared that this study has received no financial support.

\section{REFERENCES}

1. Wang GJ, Gao CF, Wei D, Wang C, Ding SQ. Acute pancreatitis: etiology and common pathogenesis. World J Gastroenterol 2009;15:1427-30.

2. Pandol SJ, Saluja AK, Imrie CW, Banks PA. Acute pancreatitis: bench to the bedside. Gastroenterology 2007;132:1127-51. Erratum in: Gastroenterology 2007;133:1056. [CrossRef]

3. Wang X, Xu Y, Qiao Y, Pang X, Hong L, Fu J, et al. An evidence-based proposal for predicting organ failure in severe acute pancreatitis. Pancreas 2013;42:1255-61. [CrossRef]

4. Triester SL, Kowdley KV. Prognostic factors in acute pancreatitis. J Clin Gastroent 2002;34:167-76. [CrossRef]

5. Knaus WA, Draper EA, Wagner DP, Zimmerman JE. APACHE II: a severity of disease classification system. Crit Care Med 1985;13:818-29.

6. Abu Hilal M, Armstrong T. The impact of obesity on the course and outcome of acute pancreatitis. Obes Surg 2008;18:326-8. [CrossRef]

7. Staubli SM, Schäfer J, Rosenthal R, Zeindler J, Oertli D, Nebiker CA. The role of CRP and Pentraxin 3 in the prediction of systemic inflammatory response syndrome and death in acute pancreatitis. Sci Rep 2019;9:18340. [CrossRef]

8. Kong L, Santiago N, Han TQ, Zhang SD. Clinical characteristics and prognostic factors of severe acute pancreatitis. World J Gastroenterol 2004;10:3336-8. [CrossRef]

9. Silva-Vaz P, Abrantes AM, Castelo-Branco M, Gouveia A, Botelho MF, Tralhão JG. Multifactorial Scores and Biomarkers of Prognosis of Acute Pancreatitis: Applications to Research and Practice. Int J Mol Sci 2020;21:338. [CrossRef]

10. Matthews DR, Hosker JP, Rudenski AS, Naylor BA, Treacher DF, Turner RC. Homeostasis model assessment: insulin resistance and beta-cell function from fasting plasma glucose and insulin concentrations in man. Diabetologia 1985;28:412-9. [CrossRef]

11. Van Biesen W, Vanholder R, Lameire N. Defining acute renal failure: RIFLE and beyond. Clin J Am Soc Nephrol 2006;1:1314-9. [CrossRef]

12. Dickstein K, Cohen-Solal A, Filippatos G, McMurray JJ, Ponikowski P, Poole-Wilson PA, et al; ESC Committee for Practice Guidelines (CPG). ESC guidelines for the diagnosis and treatment of acute and chronic heart failure 2008: the Task Force for the diagnosis and treatment of acute and chronic heart failure 2008 of the European Society of Cardiology. Developed in collaboration with the Heart Failure Association of the ESC (HFA) and endorsed by the European Society of Intensive Care Medicine (ESICM). Eur J Heart Fail 2008;10:933-89. Erratum in: Eur J Heart Fail 2010;12:416.

13. Ranson JH, Rifkind KM, Roses DF, Fink SD, Eng K, Localio SA. Objective early identification of severe acute pancreatitis. Am J Gastroenterol 1974;61:443-51.

14. Bradley EL 3rd. A clinically based classification system for acute pancreatitis. Summary of the International Symposium on Acute Pancreatitis, Atlanta, Ga, September 11 through 13, 1992. Arch Surg 1993;128:58690. [CrossRef]

15. Sarr MG. 2012 revision of the Atlanta classification of acute pancreatitis. Pol Arch Med Wewn 2013;123:118-24. [CrossRef]

16. Marshall JC, Cook DJ, Christou NV, Bernard GR, Sprung CL, Sibbald WJ. Multiple organ dysfunction score: a reliable descriptor of a complex clinical outcome. Crit Care Med 1995;23:1638-52. [CrossRef]

17. Nebiker CA, Frey DM, Hamel CT, Oertli D, Kettelhack C. Early versus delayed cholecystectomy in patients with biliary acute pancreatitis. Surgery 2009;145:260-4. [CrossRef]

18. Bakker OJ, van Santvoort HC, Hagenaars JC, Besselink MG, Bollen TL, Gooszen HG, et al; Dutch Pancreatitis Study Group. Timing of cholecystectomy after mild biliary pancreatitis. Br J Surg 2011;98:1446-54.

19. Fagenholz PJ, Castillo CF, Harris NS, Pelletier AJ, Camargo CA Jr. Increasing United States hospital admissions for acute pancreatitis, 19882003. Ann Epidemiol 2007;17:491-7. [CrossRef]

20. Bexelius TS, Ljung R, Mattsson F, Lagergren J. Cardiovascular disease and risk of acute pancreatitis in a population-based study. Pancreas 2013;42:1011-5. [CrossRef]

21. Isenmann R, Rau B, Beger HG. Early severe acute pancreatitis: characteristics of a new subgroup. Pancreas 2001;22:274-8. [CrossRef]

22. Buter A, Imrie CW, Carter CR, Evans S, McKay CJ. Dynamic nature of early organ dysfunction determines outcome in acute pancreatitis. $\mathrm{Br} \mathrm{J}$ Surg 2002;89:298-302. [CrossRef]

23. Wang S, Feng X, Li S, Liu C, Xu B, Bai B, et al. The ability of current scoring systems in differentiating transient and persistent organ failure in patients with acute pancreatitis. J Crit Care 2014;29:693.e7-11. [CrossRef]

24. Katuchova J, Bober J, Harbulak P, Hudak A, Gajdzik T, et al. Obesity as a risk factor for severe acute pancreatitis patients. Wien Klin Wochenschr 2014;126:223-7. [CrossRef]

25. Xia L, Qian KJ, Zeng ZG, Liu P, Liu F, Jiang R, et al. A clinical study of early continuous high-volume-hemofiltration in the treatment of severe acute pancreatitis. [Article in Chinese]. Zhonghua Nei Ke Za Zhi 2012;51:871-4.

26. Khanna AK, Meher S, Prakash S, Tiwary SK, Singh U, Srivastava A, et al. Comparison of Ranson, Glasgow, MOSS, SIRS, BISAP, APACHEII, CTSI Scores, IL-6, CRP, and Procalcitonin in Predicting Severity, Organ Failure, Pancreatic Necrosis, and Mortality in Acute Pancreatitis. HPB Surg 2013;2013:367581. [CrossRef]

27. Silva-Vaz P, Abrantes AM, Castelo-Branco M, Gouveia A, Botelho MF, Tralhão JG. Murine models of acute pancreatitis: A critical appraisal of 
clinical relevance. Int J Mol Sci 2019;20:2794. [CrossRef]

28. Banks PA, Bollen TL, Dervenis C, Gooszen HG, Johnson CD, Sarr MG, et al; Acute Pancreatitis Classification Working Group. Classification of acute pancreatitis--2012: revision of the Atlanta classification and definitions by international consensus. Gut 2013;62:102-11. [CrossRef]

29. Párniczky A, Kui B, Szentesi A, Balázs A, Szűcs Á, Mosztbacher D, et al; Hungarian Pancreatic Study Group. Prospective, Multicentre, Nationwide Clinical Data from 600 Cases of Acute Pancreatitis. PLoS One 2016;11:e165309. [CrossRef]

30. Yang CJ, Chen J, Phillips AR, Windsor JA, Petrov MS. Predictors of severe and critical acute pancreatitis: a systematic review. Dig Liver Dis 2014;46:446-51. [CrossRef]

\section{ORİJINAL ÇALIŞMA - ÖZ}

\section{Akut pankreatitde organ yetersizliğinin önemi ve prognostik belirteç sistemleri ile karşılaştırılması \\ Dr. Deccane Düzenci, ${ }^{1}$ Dr. Mehmet Yalnız, ${ }^{2}$ Dr. Murat İspiroğlư}

${ }^{1}$ Fırat Üniversitesi Tıp Fakültesi, İç Hastalıkları Anabilim Dalı, Elazığ

${ }^{2}$ Fırat Üniversitesi Tıp Fakültesi, Gastroenteroloji Bilim Dalı, Elazığ

AMAÇ: Akut pankreatit (AP) pankreas bezinde inaktif halde bulunan sindirim enzimlerinin çeşitli nedenlerle aktif hale geçmesi sonucunda, pankreas bezinde, çevre dokularda ve enflamasyonun yayılmasıyla sistemik bir etki gösterebilen klinik durumdur. Hastalı̆ın prognozunda en sık Ranson ve Atlanta gibi sınıflama sistemleri kullanılmaktadır. Ancak akut pankreatite bağlı gelişen organ yetersizlikleri, laboratuvar verileri ve hastaların antropometrik özelliklerinin de hastalığın şiddeti ve prognozuyla ilişkili olduğu ortaya konmuştur. Çalışmamızda AP seyrinde ortaya çıkan organ yetersizlikleri, biyokimyasal parametreler ve hastalara ait antropometrik verilerin, Ranson ve Atlanta sınflama (AS) sistemleri ile arasındaki ilişkiyi ortaya koymayı amaçladık.

GEREÇ VE YÖNTEM: AP'li 19 ile 89 yaşları arasında 153 hastanın Ranson ve Modifiye Atlanta Sınıflaması (MAS) skoru hesaplanarak laboratuvar verileri, bel çevresi, vücut kitle indeksi (VKi) gibi antropometrik verileri, organ yetersizliği tablosu araştırıldı. Gelişen organ yetersizlikleri (akciğer, karaciğer, böbrek, kalp ve multiorgan yetersizliği) Ranson değeri ve MAS skoru yüksekliğiyle ilişkili $(p<0.05)$ olarak bulundu. Çalışmaya alınan hastalardan I3'ünde (\%8.4) multiorgan yetersizliği, I7'sinde (\% I I.I) Sistemik enflamatuvar response sendromu (SIRS) gelişmiştir. On hasta (\%6.5) hayatını kaybetti. Organ yetersizlikleri, multiorgan yetersizliği (MOY) ve SIRS gelişen hastalarla hayatını kaybeden hastalar arasında yapılan istatistiksel analizde $p$ değeri $(p<0.05)$ olarak anlamlı ilişki saptandı. Bel çevresi ve vücut kitle indeksi Ranson değeriyle ilişkili saptanmazken, Modifiye Atlanta Sınıflamasıyla bel çevresi arasında anlamlı ilişki saptandı $(p<0.0$ I). Laboratuvar verilerinden üre ve ALT yüksekliği, Ranson ve Modifiye Atlanta Sınıflamasıyla ilişkili saptanırken $(p<0.00 I), 0$ ve 48. saatte bakılan $C$-reaktif protein (CRP) değerindeki yüksekliklerden sadece 48. saatteki CRP değeri Ranson değeriyle ilişkili olarak bulundu $(p<0.05)$.

BULGULAR: Organ yetersizliği, MOY, SIRS, her iki şiddet skoruyla korele olmasının yanında mortalite ile de anlamlı olarak koreleydi. Ek olarak kolesterol, trigliserit ve yatış anındaki CRP düzeyiyle mortalite arasında anlamlı korelasyon elde edilirken; kalsiyum, lipaz ve hematokrit gibi laboratuvar verileriyle anlamlı ilişki saptanmadı.

TARTIŞMA: Sonuç olarak, akut pankreatitin şiddet ve prognozunu belirlemede ve şiddetli seyreden pankreatitlerde ortaya çıkabilecek olan organ yetersizlikleri açısından dikkatli olunmasında; klasik şiddet skorlama sistemlerinin yanında hastalara ait vücut kitle indeksi, bel çevresi ve kolesterol, trigliserit, ALT, CRP gibi laboratuvar verileri önemli prognostik bilgiler vermektedir.

Anahtar sözcükler: Akut pankreatit; organ yetersizliği; şiddet skorlaması.

Ulus Travma Acil Cerrahi Derg 2021;27(4):410-420 doi: 10.14744/tjtes.2020.18552 